\title{
Study on the Cultivation of Special Industry with New Competitive Predominance for Xinjiang Economy
}

\author{
Xuefeng Wang \\ Economy \& Trade College, Shihezi University of Xinjiang \\ Shihezi 832003, China
}

Tel: 86-993-205-7130 E-mail: wxf_tea@shzu.edu.cn

\begin{abstract}
This article starts from the meanings of the special industry, analyzes the selection principle and cultivation of the special industry, discusses the cultivation of special industry for Xinjiang Province, and gives the policy advices for the development of the special industry in Xinjiang Province.
\end{abstract}

Keywords: Special industry, Competitive predominance, Cultivation

With the quick development of China economy, the differences of economic development among regions are gradually extending. Because of the special national situation of China, in the relative undeveloped region of Xinjiang, the basic status of traditional agriculture and animal husbandry is more important. Comparing with the past, the production ability of agriculture and animal husbandry has been largely enhanced, but relative to the development speed of the secondary industry and the third industry, the development speed of the agriculture and animal husbandry is relatively slow, which also restrain the development of Xinjiang Province.

Because of the vast territory, the resource gifts that various regions develop the agriculture in China are different and various regions possess different regional features and historical cultures. The development mode of regional economy in China has not a fixed standard, so different regions should select different agricultural development modes according to the regional difference features. Furthermore, the problem what we need solve is how to combine the industrial development of region with the historical cultural feature of region and look for new regional industrial development management mode, and find a new development road outside of the traditional industry. With the continually deepening of China socialism market economy reform, in the society taking the market as the basic resource deployment mode and mechanism, as viewed from the principle of maximum benefit, the growth of regional economy finally depends on the regional special industry, and the regional resource deployment with abundant efficiency should be a sort of expansion and compensation of regional special industry. As the growth point of regional economy, the special industry is mainly represented as the support driving the structure adjustment and development of county economy, the best approach to shake off the poverty and attain prosperity for the undeveloped counties, the load bringing farmers into the market, and the important channel to arrange country surplus labor force. Therefore, for the development of the Xinjiang, the most important aspect is to develop the special industry and promote the harmonious development between economy with society and the complete advancement of the society.

\section{The concept of the special industry and the principles to develop the special industry}

As viewed from the economics, the product includes manufactures, excavated products and farm produces. And in the same way, the "special product" means the products which are accreted with certain product, possess irreplaceable creation using value or appearance of same kind of product, and can fulfill popular special demands. The special industry takes the special product and special resource (including natural resource and social resource) as the base, takes the modern industrial and agricultural technologies as the supports, takes the market economy operation mode as means, surrounds the special products and special resources to implement comprehensive development, and forms the industrial system which is different with other traditional industries, possesses bright regional character, irreplaceable character, sustainable development character, competitive character, higher economical benefit and wide development foreground, and can develop the special product which can fulfill the public demands. As viewed from the geographical economics, the special industry means the industry with regional characters that can full utilize various regional advantages in the economical region based on the national economical geographical division. In a word, the special industry means the industry which can give prominence to local resource predominance and market competition and possess different characters comparing with other industries.

According to the definition of the special industry, the development of the special industry should refer to following principles. 
(1) Persisting in the orientation of the market. The industry selection of the special industry must be oriented by the market, i.e. taking the market demand, especially the competitive market demand, not the natural resource and traditional industry (product) as the essential orientation. The resource and traditional industry (product) are only bases and conditional to develop special industry. The special industry is divided into three types including the special industry based on the difference of natural resources, the special industry based on the difference of social resources, and the special industry based on the difference of comprehensive competition. The market demand is the premise to develop the industry. When the industry is conformed, we should consider not only the demands of local market, but also the needs of domestic market, and should not only research and analyze the demands of actual market, but also forecast the trend of future market demand. Otherwise, the market capacity should be fully considered.

(2) Exerting the comparison advantage. We should adjust measures to local conditions, select the industry and products with maximum local advantage to develop, form comparison advantage when the resource advantage is transformed into the industry advantage and the economic advantage as quick as possible.

(3) Paying attention to the proper centralization. To cultivate and develop the leading industry with regional character, the county region is the key part. However, the character of the county region decides that when we develop the special leading industry, we must make choice and only hold one or two industries, even several counties unite to develop one industry and really form the scale. Thus, the scale benefit can be formed and the reasonable deployment of production factors can be realized.

(4) Paying attention to the sustainable development and ecological environment optimization. The special industry must strengthen the management in the development. The management must promote the development and it is the center to develop the special industry. The management must possess the character of science, the character of modernity, and the character of operation. The management should be the behavior that every employee will to accept, and it reflects all employees' willing to pursue high efficient production values, and accords with the requirement of modern production. We must start from the human resource training to strengthen the management. So to establish the learning enterprise should be the aim for every special industry enterprise.

(5) The principle of the market orientation for the special industry. "Some things should be done, and other things should not be done". "Seeking few and seeking special".

(6) Going on the road promoting the special industry with science and technology. To enhancing the contribution ratio of high technology to the increase of special industry and to cultivate a group of special talents should be the emphasis and the difficulty to develop the special industry.

(7) The localization, export orientation and modernization are main develop trends for the regional special industry.

\section{The selection and cultivation of the special industry in Xinjiang Province}

According to above characters, the concept of industry and the principles such as high jumping-off point, proper scale, deep layer development and industrialization management to cultivate and develop the special industry, to develop the special industry in Xinjiang, we should select special industries in the national economic system and various industries, and position, cultivate and develop these special industries. Of course, with the development and utilization of the resource and the updating of the industry, some industries which are not outstanding now will be developed to the special industries, and this article will not discuss these industries.

\subsection{Developing the special industry with high added values}

The special industries take the purpose of product, making method, exchange locale and industrial management with notable features as basic characters. At the same time, the special industries must possess profitable advantage. To develop the special industry with high added values can extend the profit space for the product. For example the "four red (including tomato, safflower, medlar and capsicum)" industry has been quickly developed in recent years and formed scale industry, and it has become another new economic increase point after cotton for the development of Xinjiang economy. The extension of the industry chain makes the "four red" industry become the special industry with high added values.

\subsection{Developing the special industry in rigid cold region}

The rigid cold industry is the special resource for Xinjiang, and it can fulfill the special demands of the society. So we must try to develop various industries, such as developing green plants and precious medicinal materials in Xinjiang region, protecting and developing rare medicinal animals, developing the tour industry with beautiful natural view, delightful climate condition and harmonious human and natural environment, especially developing various kinds of special tour including mountaineering investigation tour, rare animal and plant investigation, special living tour in minority region, and establishing special tour region such as forest tour region. 


\subsection{Developing the handicraft industry of minority}

It is the traditional industry advantage in Xinjiang. We must take the demand as the aim, give priority to the handicraft, and pay attention to the products and making methods. Mostly, we should drive the green products, especially beautiful, harmonious and healthy citizen beautification and family courtyard as emphases. Therefore, we must develop the market system. The Xinjiang market is included in the national market, but the character of Xinjiang market should be kept. Based on the natural condition of Xinjiang and the industrial character, we can sale special consumables, tour remembrances and traditional handicrafts, and we can select good region to establish special market, attract consumers and drive the development of the economy. As one of basic industries in most provinces of west, the tour industry must specially emphasize the production and sale of tour remembrances.

\subsection{Developing the cultivation of livestock product industry}

Actively extend the improved beef cattle variety such as Limousin, actively organize forces to improve the variety of Tan Sheep in Xinjiang Province, enhance the meat output and the reproduction ratio, and enhance the single milk-output level and seasonal balance milk-output. As a whole, most enterprises with beef and mutton and milk manufacture have relatively small production scale, undeveloped technology, weak brand consciousness, and loose association with the market and farmers.

\subsection{Developing the cultivation of medical product industry}

First, based on the special predominant resources of Xinjiang, we must establish the modern Chinese medicine production base according with national standards, develop the modern Chinese medicine and nutrition healthy food with local features and national features, perfect the development system of Chinese medicine, promote the industrial structure adjustment through the modernization of Chinese medicine, and make the Chinese medicine industry become the special industry to drive the national economy of Xinjiang. Second, we should establish "Xinjiang Chinese medicine modern science and technology industry base", and accept it into the 10th Five Year Plan. Third, many main medicinal plants such as snow lotus with high quality and medicinal value are famous in China, and professional personnel in Xinjiang should actively exert modern medicine research technology to enhance the science and technology content of Xinjiang medicinal resource, and make the medicinal resource of Xinjiang really transform from resource advantage into economic advantage, and make the medicinal industry become the leading industry for the industrial economy in Xinjiang Province.

\subsection{Developing the cultivation of tour industry}

First, we should establish the overall arrangement of the tour industry. A tour development network arrangement with layers and emphasis should be established. To develop the special tour industry, we should strengthen the construction of the hardware, such as the tour base construction, the traffic and communication construction and the hotel construction. Second, we should strengthen the construction of tour software environment. We should increase the drumbeating force, push the series tour products with feature and influence, strengthen the tour management and enhance the content of science and technology, strengthen the training to tour managers and bring up tour managers with high quality and high standards.

\section{The necessary policy supports to develop the special industry in Xinjiang Province}

For Xinjiang, the development of the special industry is a quit long historical process. The reason is that though Xinjiang possesses good conditions and numerous special products to develop the special industry, but up to now, the special industry system with proper scale, high efficiency, radiation band and strong active function has not been formed. So the various party committees and governments should first create a loose, equal and advantageous policy environment for the development of the special industry, and the local governments should also establish some concrete policy measures to match many policy measures about the Development of the West Regions issued by the State Department.

(1) Aiming at actual situations, the municipality party committee and the government should organize relative departments and social economics experts, scholars to implement comprehensive investigation and evaluation to the special products and resources of Xinjiang, and further confirm the special industries which have been formed, filtrate special products and special resources to be developed to the special industries, list detailed list and supervise these products and resources. Based on that, the government should issue the development list of special industry to develop special industries for various regions. Various regions should select the special products and special resources which adapt the local development to cultivate and develop properly.

(2) The municipality government should establish a special management institution to develop the special industry in some relative office and bureau, and the management institution can fell in the whole development list of special industries in the whole municipality, and confirm the objective which should be firstly developed and establish the benefit policies to develop the special industry. All enterprises (including state owed enterprise, stage holding enterprise, 
collective enterprise, individual enterprise) which products belong to the range of the special industry should enjoy the benefit policy and support from the government. With the formation of special industry, the government should strengthen the consciousness of famous protection, establish the protection measures, strictly forbid imposture products and ensure the development of the special industry. For example, to support the development of the tour industry, first, we should establish the laws and regulations as quick as possible, to ensure the healthy development of special tour industry from many aspects such as organization, service and participation. Second, the government should invest certain development capital properly to improve the hardware environment of the tour industry, and quicken the development of the special tour industry.

(3) The government should establish the development and support fund of special industry for the municipality. Whether collectivity or individual which contribute for the development of Xinjiang special industry, the municipality should support them. The government should centralize strengths from various aspects, increase the science and technology degrees of special industry, attract exterior excellent results, continually quicken the self innovation steps of science and technology, try to form many science and technology results which can actually drive the special industry and possess independent intellectual property rights, and enhance the whole science and technology content of special industry in Xinjiang.

(4) The municipality government should also offer proper benefits for the enterprises or departments developing the special industry from finance, financing, revenue and land utilization. For example, the municipality, city and county should take some capitals to construct the base establishments and matching establishments for the special industry to perfect the development condition of the special industry when the finance allows, the finance department should properly broaden the load condition for the departments of the special industry, especially we should encourage that the rural credit cooperative cooperation, rural cooperative fund and other rural finance departments or civilian credit institutions provide certain short term loans with low interests to farmers in the regions which have conditions to develop the special industry, the revenue department can derate $15 \%$ of enterprise income tax for the enterprises according with the development program of special industry in the municipality, return more than $15 \%$ of special industry tax to the enterprises which have been imposed to support the development of the special industry, and for the enterprises and individuals to develop the special industry, under the strict land utilization, expropriation and approval procedures, the land management department should properly broaden the land utilization and approval conditions, and firstly consider the demands to develop the special industry under same conditions.

(5) The government should encourage large companies and enterprises with strength to participate in the development of special product and special resource in Xinjiang, which can help to quickly form the special industry of Xinjiang. The government also should adopt the measures to invite investments, propagandize the special industry list and benefit policies confirmed by Xinjiang to the whole China in order to attract exterior capitals and forces to participate in the development of Xinjiang special industry.

\section{References}

Hejian. (2005). The Policy Selection to Develop the Special Industry: the Thinking Based on "Four Reds" Industry in Xinjiang Province. Group Economics Research. No.17.

Li, Zhuqing \& Yu, Yanchun. (2001). Adjusting the western Regional Structure of Production, Developing the Advantage Industry and Regional Economy with the Different Features. Heilongjiang National Series. No.4.

Shen, Daoquan. (2001). Developing Feature Industry, Promoting the Exploitation of the Western China. Nationalities Research in Qinghai (Social Science). No.2.

$\mathrm{Xu}$, Binyou. (2005). On Financial Support and Development of Characteristic Industry in Western China. Journal of Guangdong College of Finance and Economics. No.2. 